\title{
環境パートナーシップ活動の推進施策に関する研究 〜おおつ環境フォーラムを事例として〜
}

\author{
木村 俊司 $^{1}$ 笹谷 康之 $^{2}$ \\ 1 学生会員 立命館大学大学院 理工学研究科環境社会工学専攻 \\ 2 \\ 正会員 立命館大学助理工学部助教授 理工学研究科環境社会工学専攻
}

\begin{abstract}
全国各地で市民・事業者・行政が連携する橿境パートナーシップ組織が結成されている。大津市でも「おおつ 環境フォーラム」の設立が準備されている。そこで、同フォーラムの戦略的な施策立案のために、市民・市民団 体・企業・学校を対象とした 2 種類のアンケートを実施した。この結果から、学校を拠点とした学区単位で将来 ビジョンを共有して協働し、連携志向の強い市民・市民団体・企業と初期段階から協㗢プロジェクトを立ちあげ、 社会システム、及び市民意識の変革につながる学区別・テーマ別の環境プロジェクト・イベントを採用すること が、今後の同フォーラムにとって、より効果的で戦略的なアクションプランとなることを明らかにした。

KEYWORD: Environmental partnership, Local agenda21
\end{abstract}

\section{1.はじめに}

1996 年の「とよなか市民環境会議」設立を皮切り に、全国各地で市民・事業者・行政が連携する 20 近くの環境パートナーシップ組織が結成されている。 ただ、どのような主体とどのようなテーマで環境パ ートナーシップ組織を運営していくべきかについて、 主体の意識に基づく実証的な研究は不足している。

大津市では 2000 年 3 月にパートナーシップで取 り組む「大津市地球環境保全地域行動計画（アジェ ンダ 21 おおつ)」を策定した。この計画推進のため の環境パートナーシップ組織である「(仮称) おおつ 環境フォーラム」(以下 : フォーラム) の設立に向け て、現在、準備会議が設けられ、各分科会に分かれ て様々な協㗢プロジェクトが検討されている。

高橋は環境パートナーシップ組織のあり方を、「異 なるセクター間での連携を図り、地域の将来ビジョ ンについて合意を得た後、将来ビジョンを達成する にあたって考慮すべき地域の課題を分析する。その 上で目標を実現するための戦略やプログラムを盛り 込んだ『アクションプラン』を、フォーラムを母体 としたワーキンググループで策定する」1）としてい る。

そこで本研究では、環境パートナーシップ組織の 活動をより効果的に推進していくために、将来ビジ ヨン達成に向けて、どのような主体とパートナーシ ップを構築して、どのようなテーマ・地域単位のア クションプランを策定・実施していくべきかを明ら かにする。

\section{2. 研究方法}

本研究では、大津市で実施した 2 つのアンケート の結果を用いる。

（1）アンケート設計

\section{(1)地球環境問題に関する大津市民意識調査}

この調査は、大津市民の地球的規模の環境問題へ の関心度、環境保全行動の実践状況及び意識、環境 パートナーシップのあり方の意識を把握することを 目的とする。

\section{(2)大津市における環境パートナーシップ調査}

大津市に拠点を置く市民団体、企業、学校のパー トナーシップのあり方に対する意識を調査し、フォ ーラムの「アジェンダ 21」推准事業について、重要 性・実現性の高い取り組み内容や、パートナーシッ プの構築方法を明らかにすることを目的とする。

表- 1 アンケート設計

\begin{tabular}{|c|c|c|}
\hline & 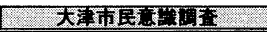 & 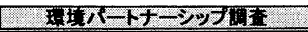 \\
\hline 调查主体 & 太津市 & 著者 \\
\hline 目的 & \begin{tabular}{|c|} 
環境保全行動における意識と \\
奉践状況の把握 \\
\end{tabular} & \begin{tabular}{|c|} 
田体の環境保全活動の状況と連携 \\
二対する意識の把握 \\
\end{tabular} \\
\hline 対象 & 大津市在住の20才以上の男女 & $\begin{array}{c}\text { 大津市内の学校と環境をテーマに取 } \\
\text { 組んでいる市民取事業者 }\end{array}$ \\
\hline 正布数 & 1000 件 & 33314 \\
\hline 回収数 & 403件(1000件中) & 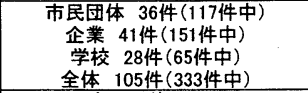 \\
\hline 回収事 & $40.3 \%$ & $\begin{array}{c}\text { 市民団体 } 30.8 \% \\
\text { 事業者 } 27.1 \% \\
\text { 学校 } 43.0 \% \\
\text { 全体 } 31.5 \% \\
\end{array}$ \\
\hline 略查期間 & 平成11年11月24日 12月8日 & 平成12年12月11日 12月31日 \\
\hline 設問数 & 22問 & 19問 \\
\hline
\end{tabular}


（2）アンケートの分析の視点

アンケートの結果を以下の視点に絞って分析した。

(1)大津市民意識調查

・市民のパートナーシップ意識

・環境保全行動の類型

- 環境意識と環境保全行動の相関性

(2)環境パートナーシップ調査

・市民団体の活動類型とパートナーシップ意識

・企業の活動類型とパートナーシップ意識

・学校のパートナーシップ意識

\section{3.大津市民意識調查の分析結果}

（1）市民のパートナーシップ意識
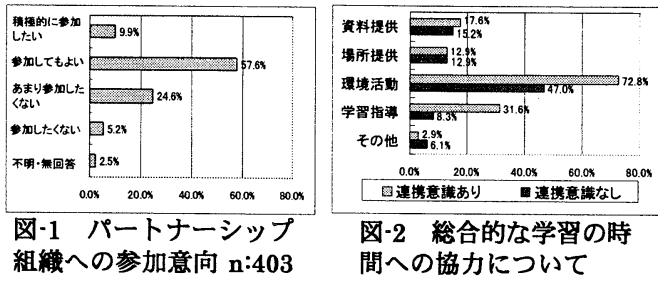

図-1より、市民の約 1 割が、フォーラムが取り 組むプロジェクトの内 容に興味があり、各種の 条件が揃えば、プロジェ クトを検討する段階か らフォーラムとの連携 が望め、約 6 割がプロ ジェクトを実施する段

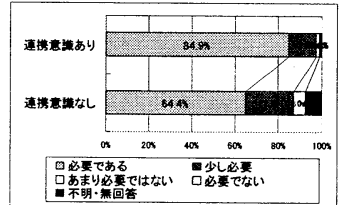
図-3 行政や事業者が計画 している情報を公開する必 要吽
階で、連携が望めることがわかる。

また、図-2、3 より、連携意識（パートナーシッ プ組織への参加意向）のある市民の 8 割以上が、地 域の環境に関する情報を必要としており、7 割以上 が子供の環境学習への協力にも積極的である。この ように連携意識のある市民は地域の環境活動への協 働参加意識も強いことがわかる。

\section{（2）環境保全行動の類型}

環境保全行動 30 項目について、古守らの手法に 従い、それぞれ環境保全行動の実施状況の指標であ る「実践スコア $\mathrm{P}$ 值小環境保全行動の取り組みや すさの指標である「効用スコア $\mathrm{E}$ 值」(表-2）の 2 つの指標を算出した 2)。

\section{表-2 実践スコアと効用スコアの定義}

\begin{tabular}{|c|c|c|c|}
\hline 实品不 & $\bar{I}$ & 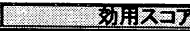 & \\
\hline$P=\sum a_{i} / 403$ & & $E=\sum b_{i} / 403$ & \\
\hline$a_{i}$ & スコア & $b_{i}$ & スコア \\
\hline 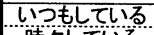 & 2 点 & 取り組やすい & 2 点 \\
\hline 時 $8 L<13$ & 1 苫 & 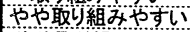 & 1 览 \\
\hline 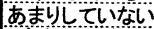 & -1 点 & やゃ取河租みに & -1 点 \\
\hline 金 $<1<1 v+1$ & -2 点 & 焣䊈2 & -2 点 \\
\hline 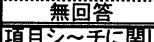 & 0 点 & 無常答 & 0 0 \\
\hline
\end{tabular}

算出された $\mathrm{P}$ 値、 $\mathrm{E}$ 值をもとにクラスター分析を 用い、項目を 3 つのクラスターに類型した。(図-4)

表-3 クラスター分析による嘸境保全行動の類型とスコア

\begin{tabular}{|c|c|c|c|}
\hline $25 \pi タ-N_{0}$ & 役周内容 & 英踥スコフP & 对用スコTE \\
\hline \multirow{14}{*}{1} & इ50分留 & 1.77 & 1.49 \\
\hline & 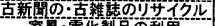 & 1.58 & 1.33 \\
\hline & 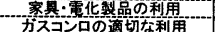 & 1.55 & 1.39 \\
\hline & 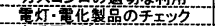 & 1.38 & 1.46 \\
\hline & 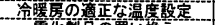 & 1.05 & 1.17 \\
\hline & 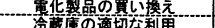 & 0.97 & 1.12 \\
\hline & 能素多才利角 & 0.86 & $\frac{1.00}{0.92}$ \\
\hline & $3 i j$-三戝入 & 0.69 & 0.81 \\
\hline & 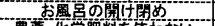 & 0.68 & 0.63 \\
\hline & 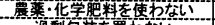 & 0.47 & 0.65 \\
\hline & 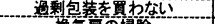 & 0.39 & 0.59 \\
\hline & 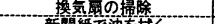 & 0.31 & 0.42 \\
\hline & 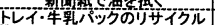 & $\frac{0.31}{0.29}$ & $\frac{0.53}{0.45}$ \\
\hline & 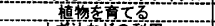 & -0.01 & 0.23 \\
\hline \multirow{5}{*}{2} & 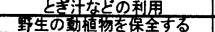 & $\frac{0.14}{130}$ & $\frac{-0.05}{1.53}$ \\
\hline & 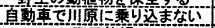 & 1.12 & $\frac{1.53}{1.40}$ \\
\hline & 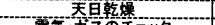 & 1.08 & 145 \\
\hline & 電槡- & 0.64 & 114 \\
\hline & 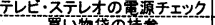 & 0.49 & 0.89 \\
\hline \multirow{5}{*}{3} & 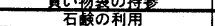 & $\begin{array}{l}0.18 \\
-0.49\end{array}$ & $\frac{0.76}{-0.14}$ \\
\hline & 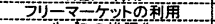 & -0.68 & -0.40 \\
\hline & 告二 & -1.08 & $=0.83$ \\
\hline & 态隄勢温水器の利用 & $\begin{array}{l}-1.36 \\
-1.38\end{array}$ & $\begin{array}{l}-0.82 \\
-0.89\end{array}$ \\
\hline & 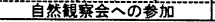 & -1.48 & -0.94 \\
\hline
\end{tabular}

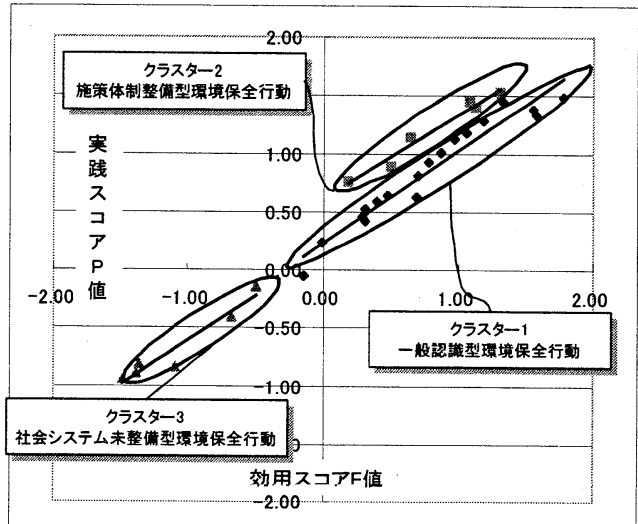

図・4 環境保全行動の実践・効用スコア分布

(1)クラスター $1 \cdots$ 一般認識型琹境保全行動 (18 項目)

ほとんどの項目の実践スコア $\mathrm{P}$ 值、効用スコア $\mathrm{E}$ 值が正の值を示している。これは、クラスター1に 含まれる行動が社会システム、市民の意識という二 つの面からみても、環境保全行動としてある程度定 着した状態といえる。

両値がともに 1.0 を越えるものは、「ゴミの分別小 「古新聞、古雑誌のリサイクル、「家具の長期利用」 などであり、これらの項目は昔から習慣として取り 組まれているため、両スコアが高い得点を示したと 考えられる。

(2)クラスター $2 \cdots$ 施策体制整備型環境保全行動（6 項目)

全ての項目が第 1 象現にプロットされているが、 群の近似直線の $\mathrm{y}$ 切片が高いため、全体的に効用ス コア $\mathrm{E}$ 值が実践スコア $\mathrm{P}$ 值を常に上回っている。こ れは一般的に睘境保全行動としては認識されている が、その割には実践されていないことを示す。 
(3)クラスター $3 \cdots$ 社会システム未整備型環境保全行 動 (6 項目)

全ての項目の実践スコア $\mathrm{P}$ 值、効用スコア $\mathrm{E}$ 值が ともに負の值を示している。これは、クラスター3 に含まれる行動が、一般的に睘境保全行動として認 識され、なおかつ実際に取り組まれるためには、社 会システム全体の整備とともに、市民の意識を改革 する必要があることを示す。

\section{（3）環境意識と箇境保全行動の相関分析}

環境に関する意識向上のために、どのような環境 保全行動の実践が強く起因しているのかを明らかに するため、環境に関する様々な意識（表-4）を目的 変数 (目的)、環境保全行動の実践を説明変数 (原因) に置いて、数量化II類を用いたアイテム分析、カテ ゴリー分析を試みた。特に相関が強かったパートナ ーシップ組織への参加意識と環境保全行動の相関分 析の結果を表-5,6 に示す。

\section{表-4 各種の環境意識}

\begin{tabular}{|c|c|}
\hline 問 & 内容 \\
\hline 問1 & 地球的規模の環境問題への関心の程度 \\
\hline 問3 & 地球温暖化に対する危機意識 \\
\hline 問5 & 環境問題の対策に筤する意識 \\
\hline 問6 & 大津市の環境問題の対策に対する期待 \\
\hline 問7 & 地球的規模の環境問題の原因主体 \\
\hline 問16 & パートナーシップ組織への参加意向 \\
\hline
\end{tabular}

表-5 分析の精度（判別的中点 $=-0.1352 ）$

\begin{tabular}{|c|c|c|c|}
\hline 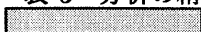 & 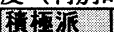 & 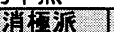 & 觔 \\
\hline 判別的中点より大 & 34 & 42 & 76 \\
\hline 判別的中点より小 & 6 & 321 & 327 \\
\hline 計 & 40 & 363 & 403 \\
\hline 判別的中率 & & & $88.1 \%$ \\
\hline 相関比 & & & 0.3990 \\
\hline
\end{tabular}

*ここでは、璑境に関するパートナーシップ組織があれぱ 参加するかという問いに対して「積糧的に参加したい」と 回答したサンプルを「積電派」、それ以外の回答をしたサ ンプルを「消極派」としている。

表-6 環境意識の判別に影鳘の大きい舞境保全行動 n:403

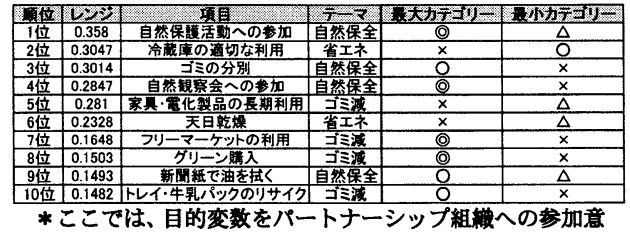

*ここでは、目的変数をパートナージ
向とした数量化 II 類の結果を示す。

表中の記号について、○:「いつも取り組んでいる」、：

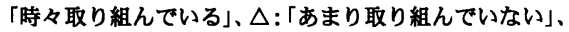
X :「全然取り組んでいない」を示す。

表 - 6 より、クラスター3（社会システム未整備型 環境保全行動）に含まれ、かつイベント性の高い項 目である「自然保護活動への参加」、「自然観察会へ の参加」、「リーマーケットの利用」に着目すると、 目的変数の寄与度を表すレンジの順位が上位に位置 していることがわかる。さらに、表-5 での積極派の プロフィールを表す最大カテゴリーが全て「いつも
取り組んでいる」となっていることから、これらの 項目がパートナーシップ組織への参加意向に大きく 寄与していることがわかる。

\section{4.睘境パートナーシップ調查の分析結果}

（1）市民団体の活動類型とパートナーシップ意識 市民団体 36 団体に ついて、アンケート 項目を集約するため、 7 つの質問項目に対 して主成分分析を行 った（表-7）。

得られた主成分得 点からクラスター分 析を用いて市民団体、 企業の類型を行った。 主成分分析の結果、 第 1 軸は活動状況軸、 第 2 軸は連携対象に 望む連携効果認識軸 であった（表-8、9）。 クラスター分析の結 果、市民団体を 6 つ のグループに類型し た（表-10）。 表-7＼cjkstart噮境パートナーシップに 関する質問項目

\begin{tabular}{|c|c|}
\hline 吾闻的自 & 自签爆目 \\
\hline 環境活動状況 & 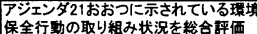 \\
\hline \multirow{5}{*}{ 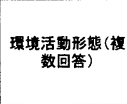 } & 昌常的な理境保全活動 \\
\hline & イヘント的な自然锱祭なと \\
\hline & 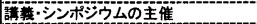 \\
\hline & 藏查-研究·提意 \\
\hline & 笑他 \\
\hline \multirow{5}{*}{$\begin{array}{l}\text { フォーラムとの協保 } \\
\text { 意向(被数回答) }\end{array}$} & 情報発但事菜 \\
\hline & 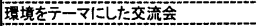 \\
\hline & 地域少一多一莤成事萧 \\
\hline & 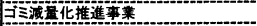 \\
\hline & 環境美花活動 \\
\hline \multirow{4}{*}{ 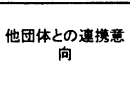 } & 連捧さるつもり \\
\hline & 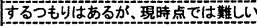 \\
\hline & 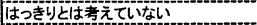 \\
\hline & 連㩲するつも河はない \\
\hline \multirow{7}{*}{ 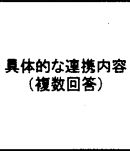 } & 人材提供 \\
\hline & 玉少提供 \\
\hline & 叙金の提筷 \\
\hline & 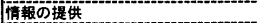 \\
\hline & 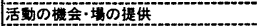 \\
\hline & 萿動の匦点の提借 \\
\hline & 特に考えていない \\
\hline \multirow{3}{*}{ 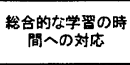 } & 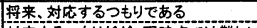 \\
\hline & 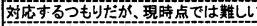 \\
\hline & 捋来、対仙するつもらはない \\
\hline \multirow{5}{*}{$\begin{array}{c}\text { 棇合的な学䏨の時 } \\
\text { 間の対応容(褑 } \\
\text { 数回诺) }\end{array}$} & 䛾師の派逗 \\
\hline & 教材の㜔拱 \\
\hline & 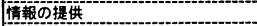 \\
\hline & 施設の提斯 \\
\hline & 专の他 \\
\hline
\end{tabular}

表-8 市民団体の各主成分の特徴

\begin{tabular}{|c|c|}
\hline . & - \\
\hline 活動状沼粗 & 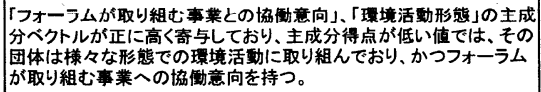 \\
\hline 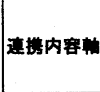 & 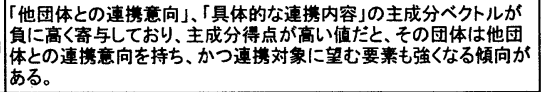 \\
\hline
\end{tabular}

表-9 市民団体が取り組む舞境保全行動 の主成分ベクトル

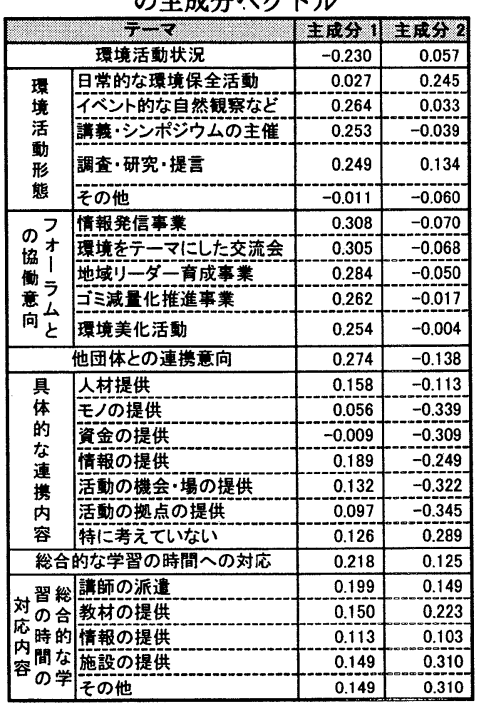




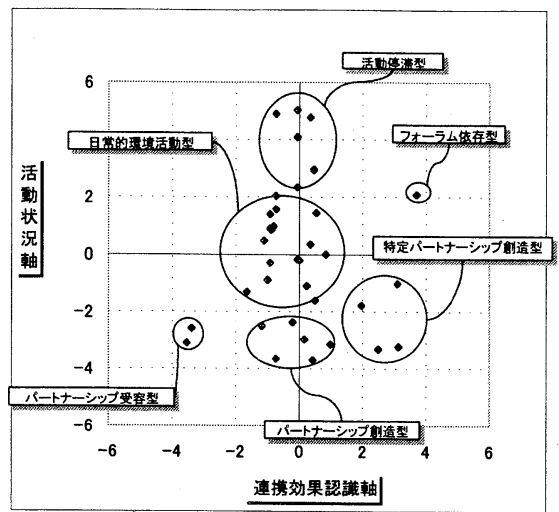

図-5 市民団体の主成分得点分布 $n: 36$

表-10 市民団体の各クラスターの特徵

\begin{tabular}{|c|c|c|c|c|c|c|c|c|c|}
\hline 다료 & x*30860 & aves & aII & nened & mingस्टा & in: & 4:5内a & 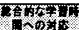 & 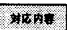 \\
\hline 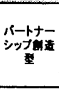 & 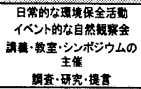 & 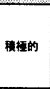 & $\begin{array}{l}\text { 筷金不足 } \\
\text { 人构不是 }\end{array}$ & $=$ =ニースレタ & 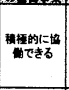 & 0 & 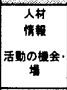 & Frative & 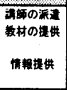 \\
\hline 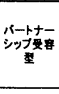 & 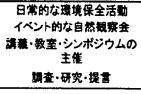 & 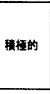 & その地 & $\begin{array}{c}\text { ハンルット } \\
\text { マスコミ } \\
\text { 呹 } \\
\end{array}$ & $\mid$ & 0 & その继 & 0 & 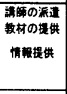 \\
\hline 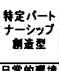 & 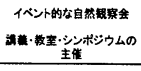 & 捰炡的 & $\begin{array}{l}\text { 放金不足 } \\
\text { 人林不足 } \\
\end{array}$ & ホームベージ & 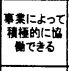 & 0 & 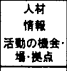 & 0 & 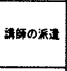 \\
\hline 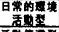 & 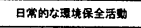 & 和柱的 & 金金一人村不足 & ハンフルトト & やや洲梗的 & $\Delta$ & - & $\Delta$ & - \\
\hline 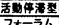 & F倍 & 清和的 & & $=$ & 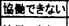 & $x$ & $=$ & $\Delta$ & $=$ \\
\hline 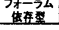 & - & 消鈢的 & 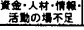 & その地 & 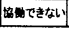 & 0 & 人林 & $\Delta$ & - \\
\hline
\end{tabular}

*表中の記号について、O :「積婳的な連费・対応意向がある」、

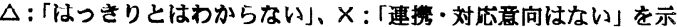
す。

(1)パートナーシップ創造型…構成比 $16 \%$

多様な環境活動を積極的に取り組み、フォーラム との協働事業に連携できると回答している。さらに、 団体活動で不足する経営資源と、連携により得られ る経営資源とのバランスがとれているため、フォー ラムとの総合的な連携が可能である。

(2)パートナーシップ受容型・..構成比 $5 \%$

特定テーマに関して取り組んでいる団体で構成さ れている。多様な活動形態で積極的に取り組んでお り、連携意向はあるが、連携効果に特に期待をして いない。特定のテーマについて、全国的交流には情 報収集などのメリットを感じているが、地域での交 流に関しては、連携対象に経営資源を得るというメ リットを期待せず、参加者へのサービスに満足して いる。

\section{(3)特定パートナーシップ創造型…構成比 $11 \%$}

イベント的な自然観察会や学習会・シンポジウム を積極的に取り組んでおり、他団体との連携意向が ある。連携による効果の期待度が強いため、事業の テーマ性があえば他団体との連携意識は強くなる。 また、イベント的な自然観察会や学習会・シンポジ ウムを積極的に取り組んでいるため、総合的な学習 の時間などの睘境学習に関して連携が望める。

\section{(4)その他の市民団体}

その他の団体として、フォーラム依存型、日常的 環境活動型、活動停帯型に類型できた。（表-10）

（2）企業の活動類型とパートナーシップ意識 企業 41 社についても、同様の設定で分析を行い、 その結果、6つのグループに類型した（表-12）。

表-11 企業が取り組む環境保全行動の 主成分ベクトル

\begin{tabular}{|c|c|c|c|}
\hline \multicolumn{2}{|c|}{$\tau-\nabla$} & 主成坐 1 & 主成分 2 \\
\hline \multicolumn{2}{|r|}{ 環境活動状況 } & 0.076 & 0.060 \\
\hline \multirow{5}{*}{ 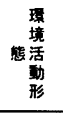 } & 旦常的な㻴境保全活動 & 0.045 & 0.037 \\
\hline & イベト的な自然制繁なE゙ & 0.015 & -0.004 \\
\hline & 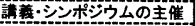 & 0.029 & 0.081 \\
\hline & 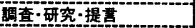 & 0.045 & 0.106 \\
\hline & その地 & -0.001 & 0.002 \\
\hline \multirow{5}{*}{ 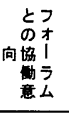 } & 情報発停事業 & 0.407 & -0.281 \\
\hline & 境境をテ一マにした交流会 & 0.336 & -0.330 \\
\hline & 地渽门二歹一章成事咅 & 0.407 & -0.179 \\
\hline & J゙滑冝华推準事莱 & 0.482 & -0.190 \\
\hline & 喂境美化活動 & 0.392 & 0.120 \\
\hline \multicolumn{2}{|r|}{ 他団体との連拴意向 } & 0.286 & 0.595 \\
\hline \multirow{7}{*}{ 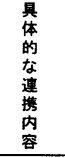 } & 人林提供 & 0.059 & 0.145 \\
\hline & 玉人の提㙋 & 0.020 & 0.047 \\
\hline & 資金の提借 & 0.015 & 0.027 \\
\hline & 情報の提供 & 0.050 & 0.100 \\
\hline & 活勤の權会-䭪の提供 & 0.022 & 0.042 \\
\hline & 活動の㧺点の提供 & 0.042 & 0.054 \\
\hline & 特に考えていない & -0.002 & 0.002 \\
\hline \multicolumn{2}{|c|}{ 耛合的な学習の時間への対庁 } & 0.240 & 0.523 \\
\hline \multirow{5}{*}{$\begin{array}{l}\text { 対習粹 } \\
\text { 虑合 } \\
\text { 内時的 } \\
\text { 容の間な学 } \\
\end{array}$} & 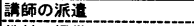 & 0.064 & 0.096 \\
\hline & 教材の提供 & 0.041 & 0.000 \\
\hline & 情報の提供 & 0.059 & 0.170 \\
\hline & 施設の提供 & 0.039 & -0.010 \\
\hline & その他 & -0.003 & 0.050 \\
\hline
\end{tabular}

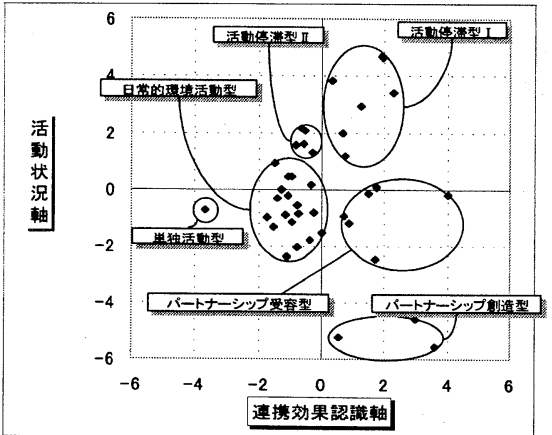

図-6 企業の主成分得点分布 $\mathrm{n}: 41$

表-12 企業の各クラスターの特徵

\begin{tabular}{|c|c|c|c|c|c|c|c|c|c|}
\hline sents: & - & xyen & 78 & In & & & 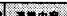 & & \\
\hline 年 & 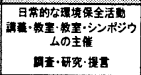 & 恝的 & 入林不足 & $\mid \begin{array}{l}\text { ホームヘーシ } \\
\text { ハンコルトな }\end{array}$ & 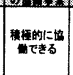 & 0 & 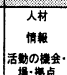 & 0 & 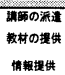 \\
\hline 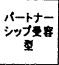 & 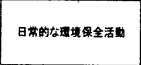 & 䒈的的 & $\begin{array}{l}\text { 妾金不足 } \\
\text { 人材不足 }\end{array}$ & $\begin{array}{c}\text { ニュースレタ- } \\
\text { ホームベージ } \\
\text { マスコミ }\end{array}$ & 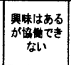 & 0 & 人林 & 0 & 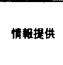 \\
\hline 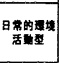 & 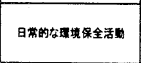 & 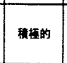 & 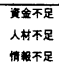 & \begin{tabular}{|c|} 
木ームページ \\
バルルトなど \\
マスコミ
\end{tabular} & 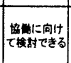 & $\Delta$ & - & $\Delta$ & - \\
\hline 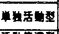 & 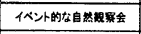 & 用的的 & tの地 & 手地 & 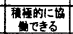 & $\times$ & - & $x$ & - \\
\hline 辞 & 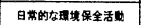 & 也海精的 & - & - & 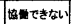 & $x$ & - & $x$ & - \\
\hline & 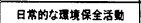 & 消梅的 & - & バルレ外衣 & r孝ない & $x$ & - & $\mathrm{x}$ & - \\
\hline
\end{tabular}

(1)パートナーシップ創造型…構成比 7\%

日常的な環境保全活動、調査・研究・提言を積極 的に取り組んでいる。フォーラムとの協働意向、他 団体との連携意向があり、その効果として人材、モ ノ、情報、活動の機会・場・拠点と様々な要素を認 識している。 
(2)パートナーシップ受容型…構成比 $15 \%$

日常的な環境保全活動、講義・教室・シンポジウ ムなどを積極的に取り組んでいる。連携意向がある が、実際にフォーラムとの事業に関しては、協働し にくいと回答している。これは企業が利潤を追求す る組織体制のため、連携意向があっても回答者 1 人 の一存だけでは決めることができないことを示して いる。具体的なプロジェクト内容が、その企業にと ってメリットがある場合に、フォーラムとの連携が 望める。

(3)その他の企業

その他の企業として、単独活動型、日常的環境活 動型、活動停滞型 I , II、に類型できた。(表-12）

（3）学校のパートナーシップ意識

以下に学校のパートナーシップ意識に関する単純 集計結果を示す。

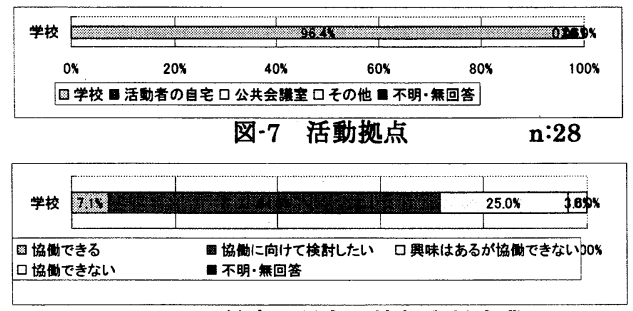

図-8 環境に関する情報発信事業 $\mathrm{n}: 28$

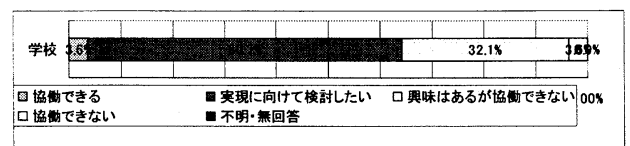

図-9 䀾境に関する学習・研修事業への協働 $\mathrm{n}: 28$

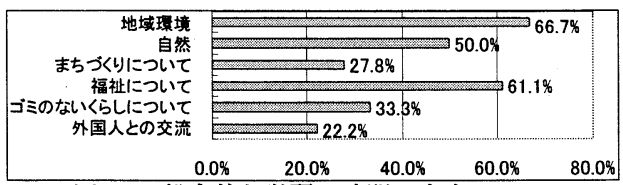

図-10 総合的な学習の時間の内容 $\mathrm{n}: 16$

図-7〜10より、地域環境リーダーを育成する無境 に関する学習・研修事業及び情報発信事業に対して、 9 割以上の教員が興味を持っていることがわかる。 さらに、総合的な学習の時間で、地域の環境学習を 予定している学校が $2 / 3$ と多いことから、教員は子 ぞもの地域社会への参加を重要視している。

\section{5.フォーラムの役割}

これまでの調査・分析結果と準備会議での議論に より、フォーラムが取り組むべき事業とその実施の 仕組みについて考えると、図-11 のようになる。

パートナーシップ組織の機能として、高橋は以下 の(3)を除く 5 点を挙げている壮り。

\section{(1)会員間の情報交換}

図-11 での「広報委員会」が有する機能である。 ニュースレター、Web ページなどによりフォーラム や行政の環境情報を提供する。

(2)睘境に関するイベントやシンポジウム

図-11 での「イベント実行委員会」が有する機能 である。イベント・シンポジウムを開き、参加者の 環境意識の向上を促す。

(3)学習・研修事業

(4)協働型プロジェクトの立案・実施、行動計画の策 定

3)、(4)はともに図-11 でのプロジェクトが有する 機能である。パートナーシップにより実現できる重 要で先導的なプロジェクトである。これらのプロジ エクトは、学区別とテーマ別とで別れている。(3)は、 環境リーダー・コーディネーターの人材育成である。 (5)計画の進行管理への関与と計画の進渉状況の点 検・検証・評価

図-11 での「進行管理委員会」が有する機能であ る。環境報告書の作成、活動の点検・評価など、フ オーラムの進行管理を行う。

\section{(6)行政に対する市民提案の空口}

図-11 での「運営会議」「新事業検討委員会」が 有する機能である。行政に対する市民提案の取りつ ぎの他に、新たな環境ミッションを感じた市民が新 事業を提案する場である。

高橋が挙げた機能とは別に、機能(3)を加えた理由 は、以下の点である。

・連携意識の強い団体は、人材が不足しており、フ オーラムのプロジェクト内容として、地域の環境リ ーダー、コーディネーターの人材育成を望んでいる。 ・連携意識の強い市民・市民団体・企業は、地域で の学習意識も強い（図-1,2、表-8,9）。

・現在、フォーラム準備会議の各分科会で、特定の テーマに関しての学習会や、環境学習に関するプロ ジェクトが検討されており、このコーディネーター が必要とされている。

よって、(3)の機能を地域の環境リーダー、コーデ イネーターの人材育成として捉え、合わせて(1) (6) の機能をフォーラムが持つべき機能とした。

\section{6.まとめ}

本研究より明らかとなった今後のフォーラムのあ り方を、以下の 3 点についてまとめる。

\section{（1）セクター間の連携のあり方}

パートナーシップ創造型の市民団体や企業は、有 志の市民とともに、プロジェクトを検討する初期段 階からフォーラムの場で計画、運営方法の検討を行 
い、必要なステイクホルダーへの参加の呼びかけを 行い、プロジェクト実施の中核となることが期待で きる。さらに、プロジェクトの内容次第では、特定 テーマに関して取り組んでいる特定パートナーシッ プ創造型の市民団体と、初期段階からの連携も期待 できる。具体的なプロジェクトの内容・効果が明確 になった段階では、ふさわしいテーマに関するパー トナーシップ受容型の市民団体・企業のプロジェク トへの参加を求めることが必要である。

（2）ローカルアジェンダ 21 を実施する地域単位 2002 年からの総合的な学習の時間の本格導入や、 学校完全週休二日制の実施や、余裕教室の有効活用 などにより、これからは学校を拠点とした地域での 環境学習が重要となる。アンケート結果では、連携 に前向きな市民・市民団体・企業は総合的な学習の 時間に積極的な姿勢を示し、地域の情報や講師の派 遣などの対応ができると回答している。6 割以上の 学校が総合的な学習の時間に地域環境の学習を取り 入れることを予定している。

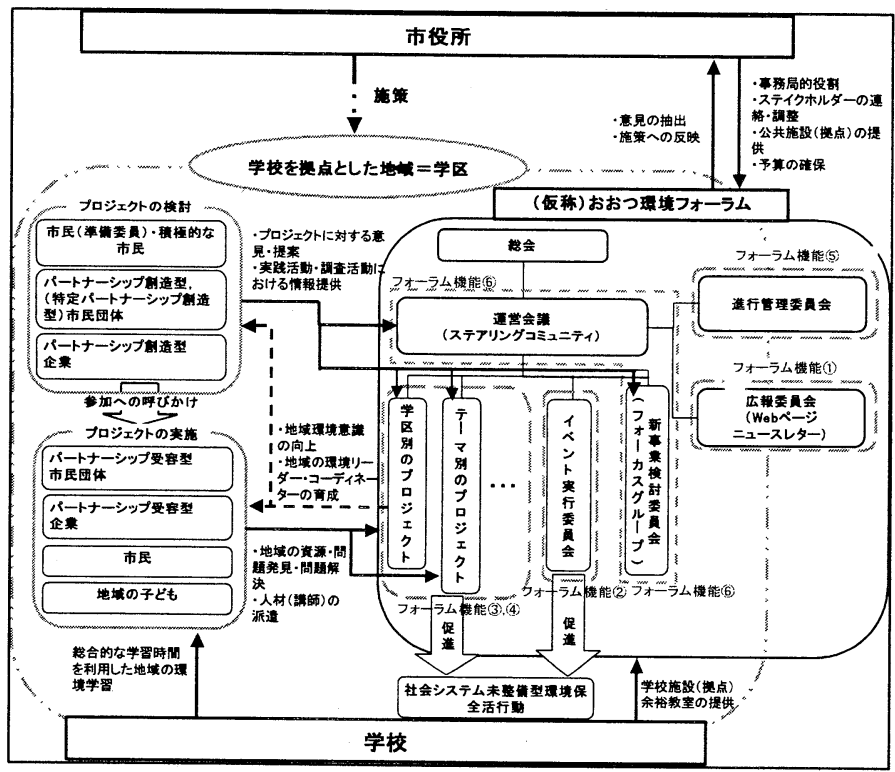

図ー11 フォーラム組蟣案とパートナーシップ形成
よって、フォーラムが戦略的にコーディネートし て、学校を拠点とした学区単位での将来ビジョン、 つまりコミュニティー・ローカルアジェンダ 21 に ついて合意、策定、及び実施することが必要である。

\section{（3）アクションプランの内容の設定}

各種の環境意識と社会システム未整備型環境保全 行動の実践との間に、強い相関性があることがわか つた。つまり環境パートナーシップ意識が高い人ほ ぞ、まだ取り組む人が少なくて、仕組みが不十分な 環境保全行動に、先駆的に取り組んでいると言える。

そこで、フォーラムが取り組む内容として、社会 システム、及び市民の意識変革につながるような環 境保全行動に重点を絞って、学区別、テーマ別のプ ロジェクト、及び交流イベントを採用すれば、より 効果的な「アクションプラン」を設定できることが わかった。

\section{A study on promotion measures of environmental partnership activity}

\section{Shunji Kimura Yasuyuki Sasatani}

The partnership organization with which a citizen, an entrepreneur, and administration cooperate all over the country is formed. Establishment of "Otsu environmental forum"(Following: forum) is prepared also in Otsu city. From this result, the three followings clarified about the setup of the action plan of a forum.

1. People share the future vision of own school districts, and collaborate for the achievement.

2. High citizen groups, companies, and administration of cooperation consciousness cooperate from an initial stage, and start a project.

3 . The event by the theme, which leads to a change of the consciousness of a social system and a citizen, is carried out. 